\title{
In Vitro Measurements of Cellular Forces and their Importance in the Lung-From the Sub- to the Multicellular Scale
}

\author{
Peter Kolb ${ }^{1}$, Annika Schundner ${ }^{2}$, Manfred Frick ${ }^{2, *}$ iD and Kay-E. Gottschalk 1,* \\ 1 Institute of Experimental Physics, Ulm University, 89069 Ulm, Germany; peter.kolb@uni-ulm.de \\ 2 Institute of General Physiology, Ulm University, 89069 Ulm, Germany; annika.schundner@uni-ulm.de \\ * Correspondence: manfred.frick@uni-ulm.de (M.F.); kay.gottschalk@uni-ulm.de (K.-E.G.)
}

check for

updates

Citation: Kolb, P.; Schundner, A.; Frick, M.; Gottschalk, K.-E In Vitro Measurements of Cellular Forces and their Importance in the Lung-From the Sub- to the Multicellular Scale. Life 2021, 11, 691. https://doi.org/ $10.3390 /$ life11070691

Academic Editors:

Haralambos Hatzikirou and

Pietro Mascheroni

Received: 14 June 2021

Accepted: 9 July 2021

Published: 14 July 2021

Publisher's Note: MDPI stays neutral with regard to jurisdictional claims in published maps and institutional affiliations.

Copyright: (C) 2021 by the authors. Licensee MDPI, Basel, Switzerland. This article is an open access article distributed under the terms and conditions of the Creative Commons Attribution (CC BY) license (https:/ / creativecommons.org/licenses/by/ $4.0 /)$.

\begin{abstract}
Throughout life, the body is subjected to various mechanical forces on the organ, tissue, and cellular level. Mechanical stimuli are essential for organ development and function. One organ whose function depends on the tightly connected interplay between mechanical cell properties, biochemical signaling, and external forces is the lung. However, altered mechanical properties or excessive mechanical forces can also drive the onset and progression of severe pulmonary diseases. Characterizing the mechanical properties and forces that affect cell and tissue function is therefore necessary for understanding physiological and pathophysiological mechanisms. In recent years, multiple methods have been developed for cellular force measurements at multiple length scales, from subcellular forces to measuring the collective behavior of heterogeneous cellular networks. In this short review, we give a brief overview of the mechanical forces at play on the cellular level in the lung. We then focus on the technological aspects of measuring cellular forces at many length scales. We describe tools with a subcellular resolution and elaborate measurement techniques for collective multicellular units. Many of the technologies described are by no means restricted to lung research and have already been applied successfully to cells from various other tissues. However, integrating the knowledge gained from these multi-scale measurements in a unifying framework is still a major future challenge.
\end{abstract}

Keywords: lung; force sensing; mechanotransduction

\section{Introduction}

Throughout life, the lung is exposed to mechanical forces. Mechanical forces play an important role in lung development, maturation, and function and can contribute to the pathogenesis of lung disease. Understanding lung mechanics has played a central role in understanding lung biology and respiratory physiology [1]. The mechanical forces in the lung include stretching, compressing, and shear stresses, as well as forces derived from surface tension and substrate rigidity. These are generated, sensed, and responded to at different scales-from subcellular structures to the tissue or organ level. At the organ scale, global lung mechanics have largely been inferred from pressure, volume, and flow relationships, as well as, very recently, digital image correlation techniques $[2,3]$. In recent years, novel imaging technologies, including intravital microscopy [4-6], fast synchrotron radiation CT imaging [7-9], and magnetic resonance elastography [10,11], have added information on tissue deformations on the macro- and micro-scale level and added to a better understanding of the local mechanical properties in airways and alveoli. In addition, a plethora of in vitro assays have identified the mechanical properties of lung cells, extracellular matrix, and lung tissues and highlighted the mechanisms of the mechanotransduction in the lung [12].

Based on these findings, many studies inferred detailed cellular responses to specific mechanical forces. However, the actual quantification of these forces is often difficult. A detailed understanding and characterization of the mechanical forces affecting the cellular responses is necessary to differentiate between physiological and pathophysiological 
stimuli and to better translate the findings from in vitro models to the actual in vivo situation [13]. In this short review, we give a brief overview of the mechanical forces at play on the cellular level in the lung. We focus on the technological aspects of measuring these from subcellular forces to measuring the collective behavior of cellular networks. We also want to emphasize that many of the technologies described are by no means restricted to lung research and have already been applied successfully to cells from various other tissues.

\section{Forces on Lung Cells and Tissue}

Mechanical forces generate stress at the subcellular and cellular level. Stresses deform the original shape of a body or cell and are expressed in units of $\mathrm{Pa}\left(\mathrm{N} / \mathrm{m}^{2}\right)$ [14]. The resulting deformation can be quantified by a relative length change or a relative angle change and is called strain. Strain has no unit. If the deformability is completely reversible, it is called elastic deformation. The ratio of stress and strain is then the elastic or Young's modulus. Stiff materials have a high Young's modulus, while soft materials have a low modulus. Bone typically has a Young's modulus on the order of GPa, while healthy lung tissue has a Young's of 1-5 kPa. When the lung becomes scarred and fibrotic, the Young's modulus increases manyfold and reaches values of up to $100 \mathrm{kPa}$ [15].

Cell strain or stretch in the lung has received considerable attention. Many in vitro and in vivo experiments highlighted profound effects of cell stretch on cell function. Different cell types, including epithelial, endothelial, and mesenchymal cells, are subjected to (continuous cyclic) cell stretch and compression in the lung. Part of the stretching forces in the alveolus also result from the surface tension at the air-liquid interphase, which has important effects on the alveolar micro-architecture [15]. In the alveolus, stretch stimulates cell proliferation and differentiation during fetal lung development [16-21], stimulates the secretion of pulmonary surfactant from alveolar type 2 cells [6,22-29], affects alveolar barrier function [30,31] and repair mechanisms [32], among other effects. However, stretch above the physiological range can also lead to alveolar cell and tissue damage [6,33,34], increased pro-inflammatory responses [35-37], or impaired wound healing [38,39], resulting in alveolar instability, endothelial leakage, alveolar edema, surfactant dysfunction, or tissue remodeling. These pathological changes are associated with the pathogenesis of severe pulmonary diseases, including acute respiratory distress syndrome (ARDS), ventilator induced lung injury (VILI) [40-43], and fibrosis [44,45]. Similar to the alveolus, stretching or compressing airway cells elicits multiple physiological and pathological responses. These include establishing respiration at birth and maintaining normal breathing in adults [46], airway constriction [46-48], pathological airway remodeling [49-51], the generation of proinflammatory responses [52,53], and the development of airway hyperresponsiveness [54]. Again, the dose (magnitude of stress) determines whether the outcomes are beneficial or detrimental.

Shear stress also plays a significant role within the lung. Shear stress is the force exerted per cross-sectional area and leads to the deformation of cells. It results from the movement of a fluid along a boundary. Interactions between fluid (e.g., airway surface liquid) and a boundary (e.g., epithelial cells), together with friction between fluid molecules, leads to a velocity gradient within the fluid and to a transfer of force onto the boundary. In the lung, shear stress, in particular, is induced by airflow at the air-liquid interphase of the airways. Shear stress exerted by the airflow is proportional to the changes in airway pressure [55]. Physiological levels of shear stress impact the regulation of the airway surface liquid [56,57], mucus secretion [58], and overall muco-ciliary clearance and enhance the epithelial barrier function [59]. Elevated shear stress on the epithelial cell layer might play a part in tissue damage, inflammation, and perhaps even airway remodeling [60]. In the alveoli, a special form of shear stress, interfacial stress, stimulates the secretion of pulmonary surfactant and affects the gene expression in alveolar type 2 cells [61,62]. Apart from shear stress transmitted by airflow in the airways, shear stress within blood vessels and the microvasculature is significant and impacts endothelial function [63], but it also 
contributes to the pathogenesis of pulmonary arterial hypertension or proinflammatory signaling cascades [64,65].

In recent years, forces exerted by the rigidity (stiffness) of the extracellular matrix (ECM) have received special attention. The stiffness of the ECM is defined by its elastic or Young's modulus, which is the ratio of stress and strain and characterizes the ECM's resistance to deformation in response to applied force. The healthy lung tissue has a Young's modulus of 1-5 kPa which increases manyfold and reaches values of up to $100 \mathrm{kPa}$ when the lung becomes scarred and fibrotic [66]. It has been found that ECM stiffness regulates human airway smooth muscle contraction [67]. However, ECM-dependent forces have received particular attention due to their contribution to the pathogenesis of fibrotic diseases [68-71]. Aberrant increases in matrix stiffness result in the activation of lung fibroblasts, excessive ECM deposition, and fibrotic remodeling of the lung tissue [66], whereas reducing stiffness can partially reverse a stiffness-induced myofibroblast phenotype [72]. In addition to its rigidity, the topography of the ECM, i.e., the architecture, geometry, size, and organization of the matrix network, also exerts stresses in cells, leading to changes in the cell shape or differentiation [73].

Apart from the obvious impact of mechanical forces on tissue-embedded cells that are directly exposed to stretch, shear, or ECM-dependent mechanical signals via cell-cell, cellmatrix, or cell-flow interactions, recent studies also highlighted the effects of mechanical forces on the cells of the immune system [74]. In the lung, it has been demonstrated that cyclical hydrostatic pressure initiated an inflammatory response by immune cells [75].

Excellent reviews have summarized the multiple responses to the different mechanical forces in the lung in detail $[1,70,73,76-79]$. Substantial progress has also been achieved in delineating how cells sense external physical cues and translate them into a cellular response. While force-sensing occurs in or on the plasma membrane, forces can reach deep in the cell interior and to the nucleus [80-82]. Specific mechano-transducing elements on the cell surface, including cell adhesion protein complexes, primary cilia, G proteincoupled receptors, and mechanically gated ion channels [29,83-86], have been identified in lung cells, and progress has been achieved in deciphering signaling pathways that ultimately result in physiological or pathophysiological cellular responses $[87,88]$. Part of this progress has been achieved through the development of accurate technologies for the precise application and investigation of the complex intracellular, intercellular, and cell-matrix forces affecting lung development, function, and pathophysiological processes.

\section{Cellular Force Measurement}

In recent years, a wide range of methods have been developed to measure the mechanical properties of cells, forces generated by cells, and the response of cells to external mechanical stimuli. These are divided into active and passive methods (Figure 1) [89]. When using active methods, a force is applied to a cell or cell surface, and the response of the cell to its deformation is measured. In contrast, passive methods do not apply mechanical stimuli to cells but observe how cellular forces alter the cell environment. While many methods can be upscaled for multicellular samples, the special mechanics of cell aggregates and tissue also allows for further measurement methods [90]. To characterize multicellular mechanics, a continuum approach can be used, where the local mechanics are represented as the average of local volumes containing several cells [91,92].

\subsection{Active Cellular Force Probing}

Different approaches can be applied to exert mechanical stimuli on cells or tissues and to measure their response. They can be divided into methods that deform only small parts of a cell and those that deform whole cells or tissue. 


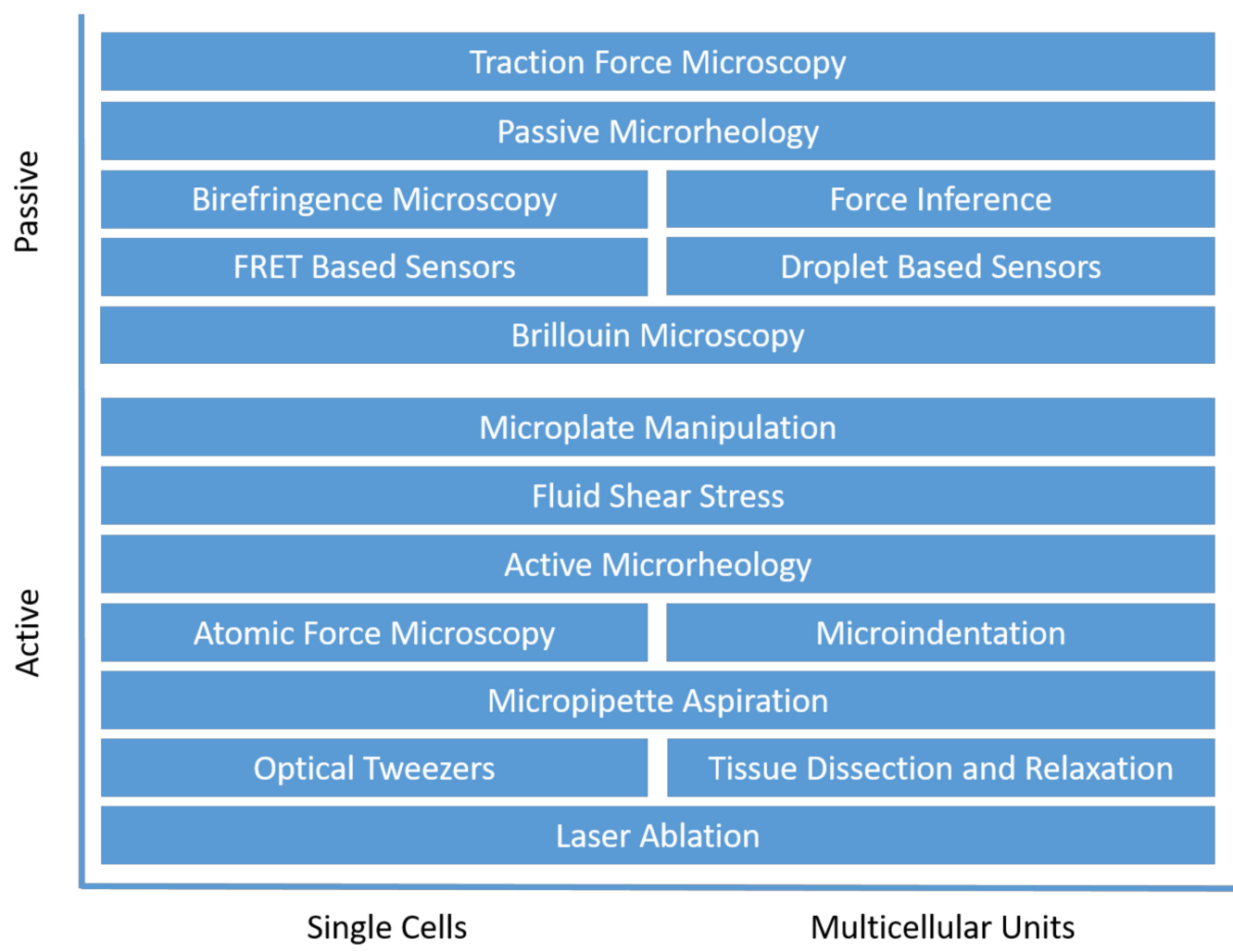

Figure 1. Overview of different methods for measuring cellular forces, organized into active and passive methods and grouped by the suitability for single-cell or multicellular unit studies.

The measurement of the mechanics at the subcellular scale requires techniques using probes in the (sub)micrometer range. The aspiration of the cell membrane into a micropipette can be utilized to deform parts of a cell surface (Figure 2a) [93,94]. Hereby, stress is applied locally by a pressure gradient between the inside and outside of the micropipette. This stress leads to cellular strain: the cell membrane deforms and gets sucked into the pipette. How much strain is induced by the applied stress is dependent on the mechanical properties of the cell. Therefore, monitoring the cell edge inside the pipette and knowing the applied suction pressure allows for calculating values like surface tension to gain insight into cell cortex mechanics, the influence of motor proteins, the viscosity of the cytoplasm of soft cells, like chondrocytes, and the elastic modulus of stiffer cells, like endothelial cells [95]. For calculating elastic properties, it is important that the strain induced by sucking in parts of the membrane does not lead to a permanent deformation but is completely reversible. Micropipette aspiration can also be used to study the mechanical properties of tissue $[96,97]$. Similar to single cells, the aspiration of tissue into larger pipette tips allows for the determination of the viscosity and the elastic modulus $[98,99]$.

In addition to inducing strain by pulling on cells, cellular mechanics can also be studied by pushing probes into the surface of cells and measuring their response. Here again, the local mechanical properties can be monitored. Pushing locally onto the cell surface allows for measuring the cortex tension (convoluted with the mechanical properties of the cytoskeleton). This can be achieved using an Atomic Force Microscope (AFM). Starting as a method for imaging the surfaces of inorganic materials [100], AFM has found its way into the field of biomechanics [101-103] and allows for gaining information about the mechanical properties [104-106] and adhesion [107] of cells. Based on the idea of measuring a force by the displacement of a spring, an AFM consists of a soft cantilever with a small tip (Figure $2 \mathrm{~b}$ ). Using the tip, forces in the $\mathrm{pN}$ to $\mathrm{nN}$ range can be exerted on the cell surface at sub-micrometer length scales, and the response is directly probed under physiological conditions [108]. To measure the displacement of the tip, a laser that reflects off the back of the cantilever onto a photodiode is used $[109,110]$. This allows for 
measurement in different environments, including under physiological conditions [108]. Besides being used as a tool for studying topography, AFM allows for the exerting of forces in the $\mathrm{pN}$ to $\mathrm{nN}$ range at sub-micrometer length scales and probe response in order to gain information about mechanical properties [104-106] and adhesion [107]. Similar to micropipette measurements, elastic and viscous properties can be determined [111-113].

A Micropipette Aspiration

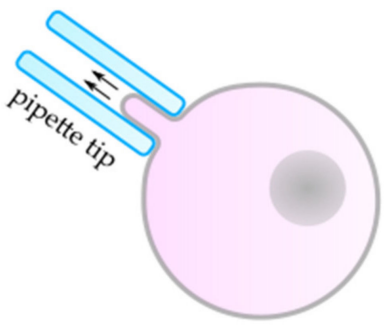

C

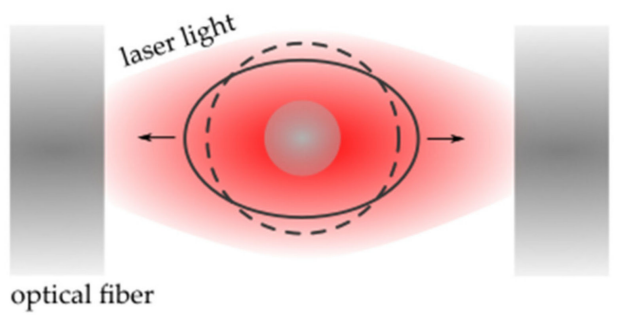

B

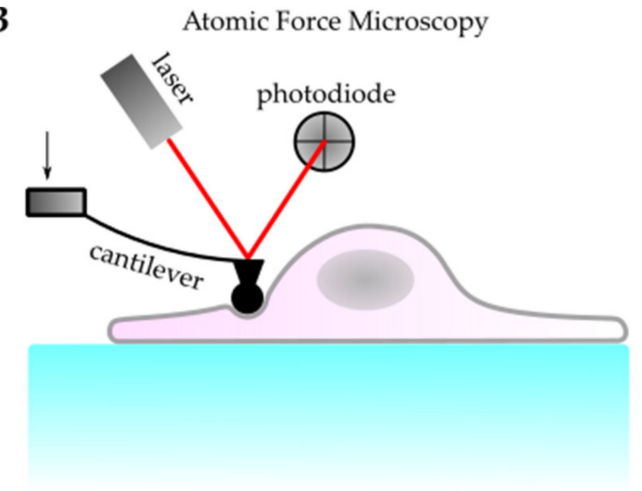

D

Active Microrheology

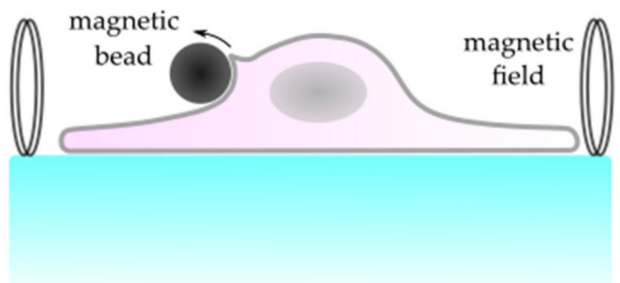

Figure 2. Schematics of active methods for measuring cellular forces and mechanical properties. (A) In micropipette aspiration, a force is applied to a cell through suction with a micropipette tip. Observation of the cell edge at known pressures allows for the determination of viscoelastic properties. (B) In Atomic Force Microscopy, a cantilever with a small tip is pressed into a cell, and its displacement is measured through a laser that reflects off its back onto a photodiode. This allows for mapping the topography and measuring the viscoelastic properties and molecular adhesion. (C) An optical cell stretcher consists of two opposing laser beams that create an electromagnetic field, which exerts forces that lead to the stretching of whole cells. Cell deformation with a calibrated system allows for the calculation of cellular elasticity. (D) Magnetic microbeads attached to a cell surface exert torque due to a magnetic field. Similar to a macroscopic rheometer, these can be used to determine the viscoelastic properties of the cell.

In order to measure the relative elastic modulus of cells, a cantilever with a spherical tip can be used. Radmacher et al. [104] showed that using the Hertz model, the relationship between the force $F_{C}$ on the cantilever and the Young's modulus $E$ of the cell is given by:

$$
F_{C}=\frac{4}{3} \frac{E}{(1-v)} \sqrt{R} \delta^{\frac{3}{2}}
$$

where $R$ is the tip radius, $v$ is the Poisson ratio, and $\delta$ is the indentation. By measuring the vertical position (distance) and the deflection of the cantilever at a known cantilever stiffness, the force distance (FD) curves can be recorded at different positions on a cell. In Figure 3a, an AFM height image of a mouse fibroblast is shown. The measured FD curves for four different positions marked in Figure 3a are shown in Figure 3b. Using Equation (1), those curves can be fitted to calculate the Young's modulus at each position. 

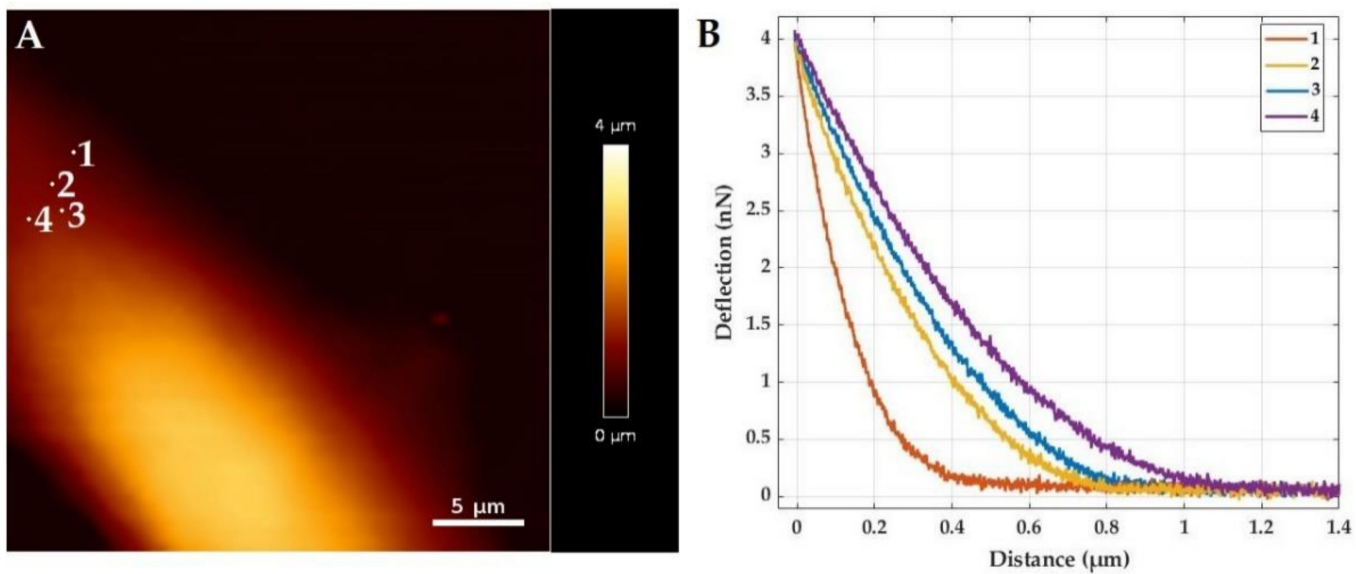

Figure 3. AFM data showing the variation in stiffness of a mouse fibroblast. (A) Measured height of a mouse fibroblast, showing the surface morphology. (B) Force distance curves taken from four different positions shown in (A).

AFM has been used to study the mechanics of different cell types [114-116] and has helped in understanding the underlying processes in various diseases, including cancer $[117,118]$.

Besides AFM, other techniques, including cell pokers apparatuses [119-122] and micro-needles [123-126], have been used to exert indentation forces on cell surfaces and measure cellular responses. At the tissue-scale, instruments with larger tips, like optical fibers [127] or micro-indenters [128], can be utilized. Instead of using small tips, microplates can be used to probe the mechanical properties of cells [129,130] or cell aggregates [131]. Centrifugation of cell aggregates and, subsequently, drop shape analysis allow for the calculation of surface tension at the macro-scale [132,133]. Since these techniques are perfectly compatible with a variety of classical imaging methods, like widefield, phase contrast, and fluorescence microscopy, applying strain locally to single cells or multicellular units can be leveraged for analyzing biochemical, strain-dependent pathways with appropriate labelling strategies.

Optical and magnetic tweezers allow for the possibility to exert and measure cellular forces in the $\mathrm{pN}$ range, without the use of cantilevers. Since the discovery that a laser beam can trap microscopic objects [134], optical tweezers have proven their utility in a wide range of biological applications [135-137]. The intensity gradient in a focused laser beam allows particles with a higher refractive index than the surrounding medium to be trapped near its center (focus). By calibrating the trap, the necessary forces to push particles out of the trap center can be measured. While often being used as a tool to study single molecules, such as kinesin [138] or myosin [139], optical tweezers also provide insight into the mechanics of larger cellular structures. Cytoskeletal transport can be investigated by introducing beads into cells [140], and the mechanical properties of the cell membrane can be investigated by attaching beads to the cell surface [141]. Similar to AFM techniques, a bead can be trapped and pushed into the cell surface to measure the elastic response [142]. Additionally, whole cells can be stretched in a setup with two opposing laser beams (Figure 2c) [143], which allows for the determination of whole cell elasticity [144,145]. This has already been used for the mechanical phenotyping of cells to detect malignant $[146,147]$ or mechanical changes of mesenchymal stem cells after doubling [148]. Optical traps have also been used to study the cell-cell-junction stiffness in cell aggregates [149]. In addition to the optical trap, magnetic tweezers can be used for active micro-rheology [150]. Similar to a macroscopic rheometer, intracellular ferromagnetic microbeads are twisted in a magnetic field [151] to determine the viscoelastic properties of the cytoplasm (Figure 2d) [152]. Beads attached to a cell membrane have also been used to study cellular mechanotransduction [153]. At the tissue level, large-scale methods, like magnetomotive optical coherence elastography, use similar magnetic effects [154]. 
Lasers are also used to disrupt cell-cell junctions [155] or cut through tissue [156,157]. Laser ablation of cellular structures disrupts force transmission and leads to a movement of the surrounding tissue. From the movement of the cell edges, the cell-junction tension can be inferred. At the macro-scale, a scalpel can also be used for dissection, instead of a laser [158].

To investigate the cellular mechanics of cells and tissue that are under constant shear stress, as in blood vessels or lungs, microfluidic devices [159-162] and mechanical stretchers [163-166] can be used. In these devices, the cell usually experiences a shear stress, resulting from the strained (stretched) substrate or the moving fluid. This shear stress leads to mechanical strain of the cell. Monitoring the biochemical consequences of the cellular strain induced by these techniques allows for the investigation of biomechanical signaling pathways. Altering the substrate stiffness in mechanical stretchers adds a further dimension to these investigations. With this, it is possible to apply constant or cyclic forces to single cells or layers and observe cellular responses, like the activation of mechano-sensitive piezo1 ion channels [29].

\subsection{Passive Cellular Force Mapping}

Passive cellular force mapping techniques use special molecules, particles, or substrates, instead of actively applying forces to cells. Monitoring the cells' adaptive behavior and shape changes is then used to calculate the cellular mechanics.

Observing the cellular forces of adherent cells on elastic substrates requires the tracking of substrate displacement. Initially, this was achieved by monitoring the wrinkles caused by cellular contraction on soft silicone substrates [167]. However, the methodology and resolution of traction force microscopy (TFM) have been significantly improved over the years [168]. The first improvements came with the introduction of substrates with tunable compliance and the precise measurement of substrate stiffness $[169,170]$. Since it is difficult to calculate forces from the shape of wrinkles, beads were introduced to track the substrate deformation (Figure 4a) [171,172]. With the advancement in micropatterning, substrates could be structured, and beads could be arranged in defined arrays. This enabled the study of cellular forces and their relation to the focal adhesion assembly [173]. Instead of using flat substrates, it is also possible to seed cells on micropillars (Figure 4b) [174] for the accurate tuning of the substrate stiffness [175] and precise calculation of the cellular forces exerted on individual pillars [176]. The relation between the force $F$ applied by a cell to one pillar and the deflection $\delta$ is given by:

$$
F=\frac{3 E I \delta}{L^{3}}
$$

where $E$ is the Young's modulus, $I$ is the moment of inertia, and $L$ is the pillar length [174]. Figure 5a depicts a smooth muscle cell sitting on top of such a micropillar array (from Tan et al. [174]). The fluorescently stained fibronectin allows for the calculation of the force applied by the cells. Additional staining of focal adhesion protein vinculin (Figure 5b, from [174]) revealed a relation between the generated force and the area of focal adhesion staining per post (Figure 5c). Since tracking of the micropillar displacement can be challenging, improvements have been made by introducing nanoparticles for large-area and high-precision tracking [177]. Besides seeding cells on a deformable substrate, it has also been shown that subcellular forces created by individual adhesive contacts can be measured by allowing adherent cells to attach to the lever of a specifically micromachined device [178]. TFM can further be used to study cell aggregates and tissue [179], and techniques have been developed that can track forces of cells embedded in gels, which allow for the study of stresses in three-dimensional systems mimicking physiological conditions [180]. TFM substrates can also be incorporated into many other devices [181], including microfluidic channels [182,183] or cell stretchers [184], and have been used to study force generation during morphogenesis [185]. While it is difficult to track forces inside tissues due to the 
lack of a substrate, droplets have been introduced into tissues, and their deformation has been used to determine cell-generated forces [186].

A

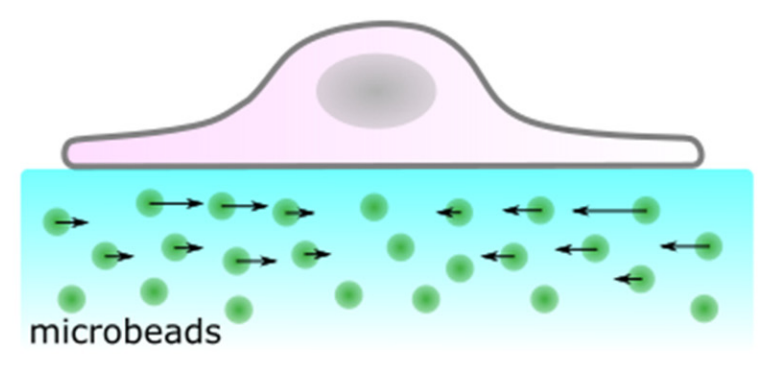

C Förster Resonance Energy Transfer based tension sensor

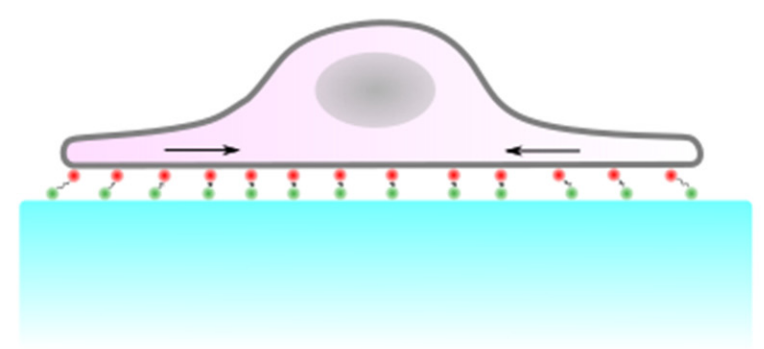

B

Traction Force Microscopy with micropillars

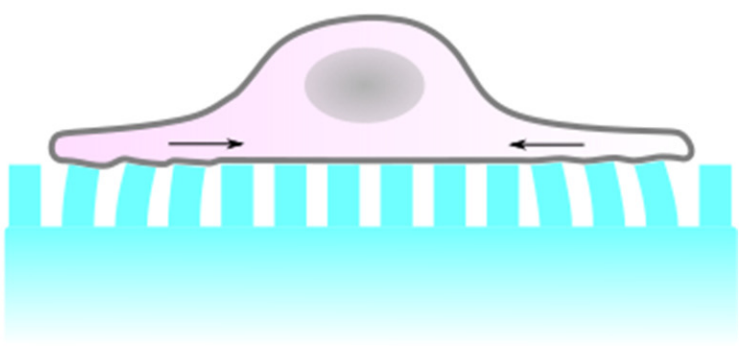

$\mathrm{D}$ Passive Microrheology

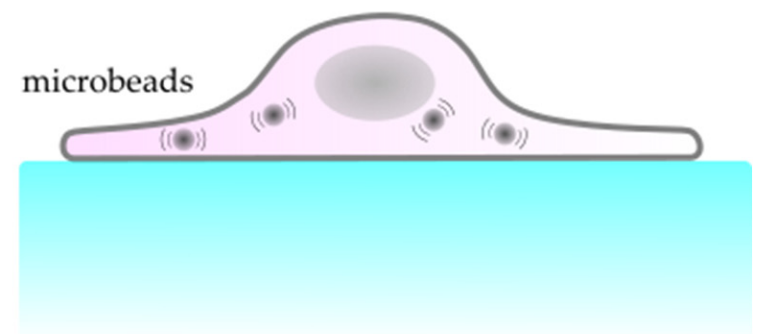

Figure 4. Schematics of passive methods to measure cellular forces and mechanical properties. (A) Embedding fluorescent beads in substrates with a known compliance allows for the mapping of cellular traction forces. (B) The deformation of micropillars by cells seeded on top of them can be used to calculate discrete cellular traction forces. (C) Specifically engineered molecular tension sensors based on Förster-Resonance-Energy-Transfer can be utilized to measure forces at cell-substrate contacts. (D) In passive micro-rheology, the movement of beads taken up by cells, which is caused by Brownian motion, allows for the study of the viscoelastic properties of cells.

Förster-Resonance-Energy-Transfer (FRET) has been applied to track cellular forces. Initially, FRET-based sensors were developed as molecular tension sensors [187,188]. Since then, they have been used to measure force transmission in cells [189] at cell-substrate [190] and at cell-cell [191] contacts. In FRET, two fluorophores in close proximity can undergo an efficient energy transfer when the donor is excited. The transfer rate is dependent on the distance between the two molecules and allows for a precise measurement of distance changes. This can be used to create artificial molecular tension sensors for TFM (Figure 4c) [188], but it also allows for tension measurements on molecules participating in the mechanotransduction inside cells by attaching donor and acceptor fluorophores to specific molecules [192,193]. Here, the strain is directly measured: the FRET signal only changes when the distance between fluorophores changes. Hence, it can be directly measured how externally applied stress leads to internal cellular strain. Göhring et al. [194] designed a FRET-based molecular force sensor that connects a glass-supported lipid bilayer to a T-cell receptor (Figure 5d). The present forces lead to a stretching of the sensor, which moves the acceptor and donor fluorophore further apart from each other and reduces the FRET efficiency (Figure 5e). 

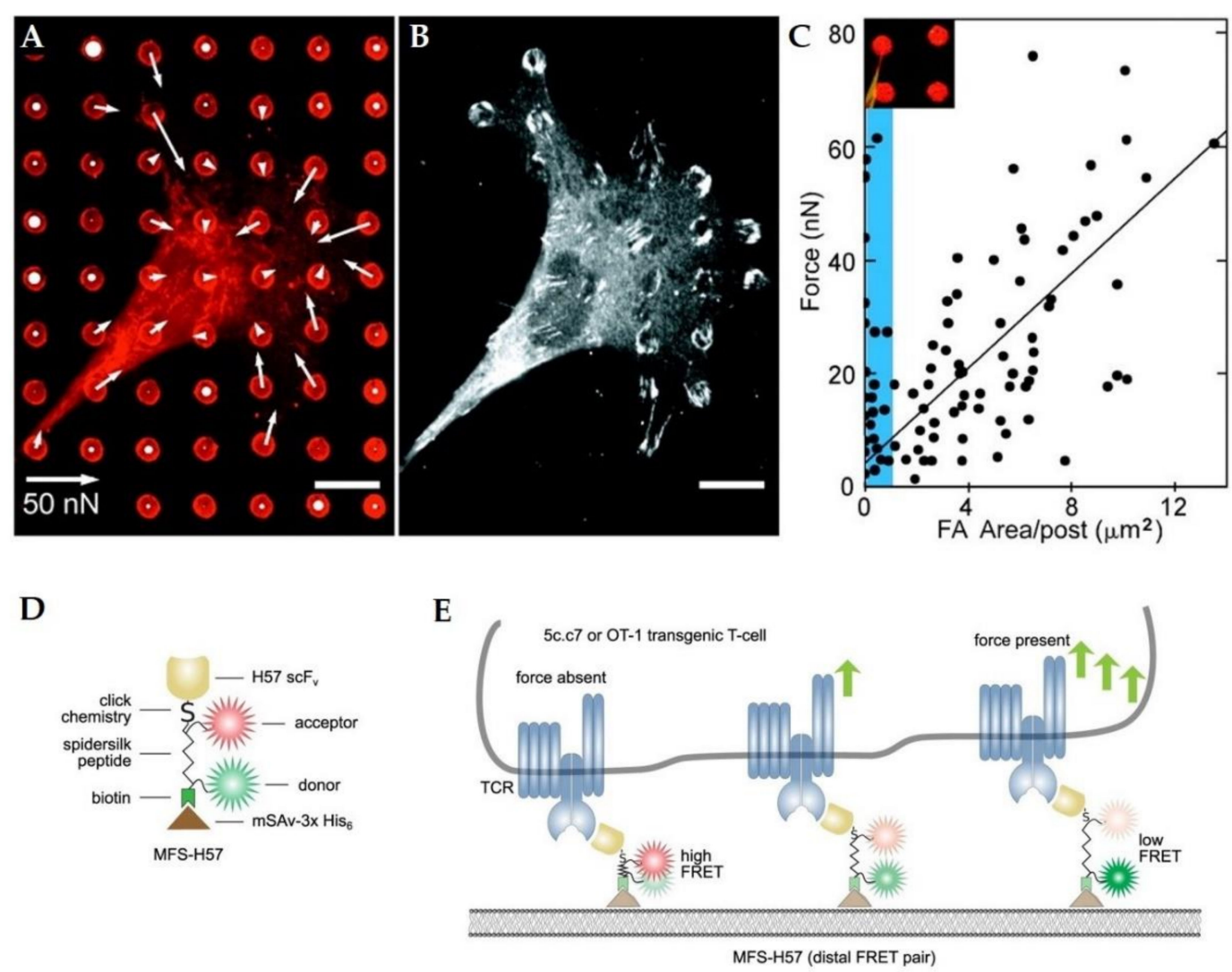

Figure 5. Passive cellular force sensors. (A) Confocal image of a smooth muscle cell on a micropillar substrate. Fibronectin staining (red) allows for the calculation of cellular forces (white arrows.). (B) Immunofluorescence staining of vinculin for the calculation of focal adhesion areas. (C) The exerted forces on each pillar in relation to the focal adhesion area per post. (Inset) Deflection of a post due to cellular force. (D) Illustration of a Förster-Resonance-Energy-Transfer (FRET)-based force sensor. (E) The exerted force leads to a stretching of the sensor, which results in a reduced FRET efficiency. (A-C) were adapted with permission from [174]. Copyright (2003) National Academy of Sciences, U.S.A. (D-E) were adapted from.

Another tool to determine mechanical properties in cells is passive micro-rheology. In contrast to its active counterpart, which uses magnetic tweezers to apply forces (see above), passive micro-rheology uses internalized microparticles that move through Brownian motion (Figure $4 \mathrm{~d}$ ). In these measurements, no strain or stress is actively induced in the cells. However, if they are combined with devices like microfluidic chambers, the effect of stress or strain on cellular mechanics can be probed. This allows for the study of the dynamic forces inside the cytoplasm and determination of the physical properties of the cytoskeletal network [195-199]. Passive micro-rheology can also be conducted with cells on different substrates, including micropatterned ones [200].

While most methods use some kind of probe or sensor to test cellular responses, novel techniques are able to directly infer forces via label-free imaging. Polarization microscopy allows for image stress anisotropy, which leads to a differences in refractive indices, called birefringence [201]. This can be used to study the substrate deformation caused by cellular traction forces, but also to determine the stress anisotropy in cells [202]. Brillouin microscopy is another emerging, non-invasive imaging technique that allows for the determination of viscoelastic properties in three dimensions [203]. It is based on the effect that acoustic phonons have due to density fluctuations, which can interact with light and lead to spectral changes caused by scattering. These spectral shifts reveal the states of photons, which can be used to determine viscoelastic properties [204]. A major advantage of this technology is that it can be applied over various scales, ranging from the sub- (intracellular) to the multicellular/tissue scale. 
In cell aggregates and tissue, stresses can also be inferred from observing cell shapes and curvatures at cell-cell contacts [205]. Known as force inference, this method has improved over the years due to computational advances [206-208]. It has especially found an application in the study of morphogenetic movements [209].

\section{Outlook}

The lung is one of the organs where the mechanical properties of cells and extracellular matrix are tightly connected to the physiological function. The well-orchestrated interplay between different cell types in the lung, together with the three-dimensional, optimized architecture [210] poses a great challenge in terms of correlating quantitative measurements of cellular and extracellular stress and strain and its relation to physiology. The abovedescribed techniques are fundamental for understanding the intricate interplay between mechanical load, cellular deformation, matrix remodeling, and the physiological function of the lung. So far, the techniques suffer from a low throughput and technical complexity, and they are often restricted to individual cells or smaller cellular units. Apart from further improving active and passive force measurement technologies, it will be of great importance to not only understand the effect of stress and strain on individual cells, but also to correlate these data with multi-cellular assays that also involve the extracellular matrix $[211,212]$. In particular, the measurement of the strain and forces in organs or whole organisms is urgently needed [213]. Many additional organs, like the bladder, heart, skin, or bone, are constantly exposed to a variety of forces. These forces are strongly coupled for function and are related to the stiffness of the tissues. Understanding and leveraging the mechanobiological response of tissue therefore bears great potential in fields ranging from stem cell reprogramming [214] to tissue engineering [215].

Author Contributions: K.-E.G., P.K., A.S., and M.F. wrote the manuscript. All authors have read and agreed to the published version of the manuscript.

Funding: This work was funded by the Deutsche Forschungsgemeinschaft (DFG, German Research Foundation)—Projektnummer(n): 278012962 (GRK “Pulmosens"), 251293561 (SFB1149), and 175083951.

Institutional Review Board Statement: Not applicable.

Informed Consent Statement: Not applicable.

Data Availability Statement: Not applicable.

Conflicts of Interest: The authors declare no conflict of interest.

\section{References}

1. Tschumperlin, D.J.; Boudreault, F.; Liu, F. Recent advances and new opportunities in lung mechanobiology. J. Biomech. 2010, 43, 99-107. [CrossRef] [PubMed]

2. Mariano, C.A.; Sattari, S.; Maghsoudi-Ganjeh, M.; Tartibi, M.; Lo, D.D.; Eskandari, M. Novel Mechanical Strain Characterization of Ventilated ex vivo Porcine and Murine Lung using Digital Image Correlation. Front. Physiol. 2020, 11, 1536. [CrossRef]

3. Arora, H.; Mitchell, R.L.; Johnston, R.; Manolesos, M.; Howells, D.; Sherwood, J.M.; Bodey, A.J.; Wanelik, K. Correlating local volumetric tissue strains with global lung mechanics measurements. Materials 2021, 14, 439. [CrossRef] [PubMed]

4. Looney, M.R.; Bhattacharya, J. Live imaging of the lung. Annu. Rev. Physiol. 2014, 76, 431-445. [CrossRef] [PubMed]

5. Grune, J.; Tabuchi, A.; Kuebler, W.M. Alveolar dynamics during mechanical ventilation in the healthy and injured lung. Intensive Care Med. Exp. 2019, 7, 34. [CrossRef] [PubMed]

6. Perlman, C.E.; Bhattacharya, J. Alveolar expansion imaged by optical sectioning microscopy. J. Appl. Physiol. 2007, 103, 1037-1044. [CrossRef]

7. Sera, T.; Uesugi, K.; Yagi, N. Localized morphometric deformations of small airways and alveoli in intact mouse lungs under quasi-static inflation. Respir. Physiol. Neurobiol. 2005, 147, 51-63. [CrossRef]

8. Lovric, G.; Mokso, R.; Arcadu, F.; Vogiatzis Oikonomidis, I.; Schittny, J.C.; Roth-Kleiner, M.; Stampanoni, M. Tomographic in vivo microscopy for the study of lung physiology at the alveolar level. Sci. Rep. 2017, 7, 12545. [CrossRef]

9. Sera, T.; Yokota, H.; Tanaka, G.; Uesugi, K.; Yagi, N.; Schroter, R.C. Murine pulmonary acinar mechanics during quasi-static inflation using synchrotron refraction-enhanced computed tomography. J. Appl. Physiol. 2013, 115, 219-228. [CrossRef] [PubMed] 
10. Goss, B.C.; McGee, K.P.; Ehman, E.C.; Manduca, A.; Ehman, R.L. Magnetic resonance elastography of the lung: Technical feasibility. Magn. Reson. Med. 2006, 56, 1060-1066. [CrossRef]

11. Bu, R.; Balakrishnan, S.; Price, H.; Zdanski, C.; Mitran, S.; Oldenburg, A.L. Localized compliance measurement of the airway wall using anatomic optical coherence elastography. Opt. Express 2019, 27, 16751-16766. [CrossRef] [PubMed]

12. Schmitt, S.; Hendricks, P.; Weir, J.; Somasundaram, R.; Sittampalam, G.S.; Nirmalanandhan, V.S. Stretching mechanotransduction from the lung to the lab: Approaches and physiological relevance in drug discovery. Assay Drug Dev. Technol. 2012, 10, 137-147. [CrossRef] [PubMed]

13. Hubmayr, R.D.; Kallet, R.H. Understanding pulmonary stress-strain relationships in severe ARDS and its implications for designing a safer approach to setting the ventilator. Respir. Care 2018, 63, 219-226. [CrossRef] [PubMed]

14. Tschumperlin, D.J.; Lagares, D. Mechano-therapeutics: Targeting Mechanical Signaling in Fibrosis and Tumor Stroma. Pharmacol. Ther. 2020, 212, 107575. [CrossRef] [PubMed]

15. Knudsen, L.; Ochs, M. The micromechanics of lung alveoli: Structure and function of surfactant and tissue components. Histochem. Cell Biol. 2018, 150, 661-676. [CrossRef]

16. Liu, M.; Post, M. Invited review: Mechanochemical signal transduction in the fetal lung. J. Appl. Physiol. 2000, 89, 2078-2084. [CrossRef]

17. Liu, M.; Xu, J.; Tanswell, A.K.; Post, M. Stretch-induced growth-promoting activities stimulate fetal rat lung epithelial cell proliferation. Exp. Lung Res. 1993, 19, 505-517. [CrossRef]

18. Foster, C.D.; Varghese, L.S.; Gonzales, L.W.; Margulies, S.S.; Guttentag, S.H. The Rho pathway mediates transition to an alveolar type i cell phenotype during static stretch of alveolar type II cells. Pediatr. Res. 2010, 67, 585-590. [CrossRef]

19. Sanchez-Esteban, J.; Cicchiello, L.A.; Wang, Y.; Tsai, S.W.; Williams, L.K.; Torday, J.S.; Rubin, L.P. Mechanical stretch promotes alveolar epithelial type II cell differentiation. J. Appl. Physiol. 2001, 91, 589-595. [CrossRef]

20. Li, J.; Wang, Z.; Chu, Q.; Jiang, K.; Li, J.; Tang, N. The Strength of Mechanical Forces Determines the Differentiation of Alveolar Epithelial Cells. Dev. Cell 2018, 44, 297-312. [CrossRef]

21. Tang, Z.; Hu, Y.; Wang, Z.; Jiang, K.; Zhan, C.; Marshall, W.F.; Tang, N. Mechanical Forces Program the Orientation of Cell Division during Airway Tube Morphogenesis. Dev. Cell 2018, 44, 313-325. [CrossRef]

22. Edwards, Y.S. Stretch stimulation: Its effects on alveolar type II cell function in the lung. Comp. Biochem. Physiol. Part A 2001, 129, 245-260. [CrossRef]

23. Wirtz, H.R.W.; Dobbs, L.G. Calcium mobilization and exocytosis after one mechanical stretch of lung epithelial cells. Science 1990, 250, 1266-1269. [CrossRef] [PubMed]

24. Frick, M.; Bertocchi, C.; Jennings, P.; Haller, T.; Mair, N.; Singer, W.; Pfaller, W.; Ritsch-Marte, M.; Dietl, P. Ca ${ }^{2+}$ entry is essential for cell strain-induced lamellar body fusion in isolated rat type II pneumocytes. Am. J. Physiol. Lung Cell. Mol. Physiol. 2004, 286, L210-L220. [CrossRef] [PubMed]

25. Ashino, Y.; Ying, X.; Dobbs, L.G.; Bhattacharya, J. Ca(2+)(i) oscillations regulate type II cell exocytosis in the pulmonary alveolus. Am. J. Physiol. Lung Cell. Mol. Physiol. 2000, 279, L5-L13. [CrossRef]

26. Patel, A.S.; Reigada, D.; Mitchell, C.H.; Bates, S.R.; Margulies, S.S.; Koval, M. Paracrine stimulation of surfactant secretion by extracellular ATP in response to mechanical deformation. Am. J. Physiol. Lung Cell. Mol. Physiol. 2005, 289, L489-L496. [CrossRef] [PubMed]

27. Tan, J.J.; Boudreault, F.; Adam, D.; Brochiero, E.; Grygorczyk, R. Type 2 secretory cells are primary source of ATP release in mechanically stretched lung alveolar cells. Am. J. Physiol. Lung Cell. Mol. Physiol. 2020, 318, L49-L58. [CrossRef] [PubMed]

28. Furuya, K.; Tan, J.J.; Boudreault, F.; Sokabe, M.; Berthiaume, Y.; Grygorczyk, R. Real-time imaging of inflation-induced ATP release in the ex vivo rat lung. Am. J. Physiol. Lung Cell. Mol. Physiol. 2016, 311, L956-L969. [CrossRef]

29. Diem, K.; Fauler, M.; Fois, G.; Hellmann, A.; Winokurow, N.; Schumacher, S.; Kranz, C.; Frick, M. Mechanical stretch activates piezo1 in caveolae of alveolar type I cells to trigger ATP release and paracrine stimulation of surfactant secretion from alveolar type II cells. FASEB J. 2020, 34, 12785-12804. [CrossRef] [PubMed]

30. Cavanaugh, J.R.; Oswari, J.; Margulies, S.S. Role of stretch on tight junction structure in alveolar epithelial cells. Am. J. Respir. Cell Mol. Biol. 2001, 25, 584-591. [CrossRef]

31. Cohen, T.S.; Cavanaugh, K.J.; Margulies, S.S. Frequency and peak stretch magnitude affect alveolar epithelial permeability. Eur. Respir. J. 2008, 32, 854-861. [CrossRef] [PubMed]

32. Ito, Y.; Correll, K.; Schiel, J.A.; Finigan, J.H.; Prekeris, R.; Mason, R.J. Lung fibroblasts accelerate wound closure in human alveolar epithelial cells through hepatocyte growth factor/c-Met signaling. Am. J. Physiol. Lung Cell. Mol. Physiol. 2014, 307, L94-L105. [CrossRef] [PubMed]

33. Tschumperlin, D.J.; Oswari, J.; Margulies, S.S. Deformation-induced injury of alveolar epithelial cells: Effect of frequency, duration, and amplitude. Am. J. Respir. Crit. Care Med. 2000, 162, 357-362. [CrossRef]

34. Hammerschmidt, S.; Kuhn, H.; Gessner, C.; Seyfarth, H.J.; Wirtz, H. Stretch-induced alveolar type II cell apoptosis: Role of endogenous bradykinin and PI3K-Akt signaling. Am. J. Respir. Cell Mol. Biol. 2007, 37, 699-705. [CrossRef]

35. Iwaki, M.; Ito, S.; Morioka, M.; Iwata, S.; Numaguchi, Y.; Ishii, M.; Kondo, M.; Kume, H.; Naruse, K.; Sokabe, M.; et al. Mechanical stretch enhances IL-8 production in pulmonary microvascular endothelial cells. Biochem. Biophys. Res. Commun. 2009, 389, 531-536. [CrossRef] [PubMed] 
36. Rentzsch, I.; Santos, C.L.; Huhle, R.; Ferreira, J.M.C.; Koch, T.; Schnabel, C.; Koch, E.; Pelosi, P.; Rocco, P.R.M.; de Abreu, M.G. Variable stretch reduces the pro-inflammatory response of alveolar epithelial cells. PLoS ONE 2017, 12, e0182369. [CrossRef]

37. Valentine, M.S.; Link, P.A.; Herbert, J.A.; Kamga Gninzeko, F.J.; Schneck, M.B.; Shankar, K.; Nkwocha, J.; Reynolds, A.M.; Heise, R.L. Inflammation and Monocyte Recruitment Due to Aging and Mechanical Stretch in Alveolar Epithelium are Inhibited by the Molecular Chaperone 4-Phenylbutyrate. Cell. Mol. Bioeng. 2018, 11, 495-508. [CrossRef]

38. Felder, M.; Trueeb, B.; Stucki, A.O.; Borcard, S.; Stucki, J.D.; Schnyder, B.; Geiser, T.; Guenat, O.T. Impaired wound healing of alveolar lung epithelial cells in a breathing lung-on-a-chip. Front. Bioeng. Biotechnol. 2019, 7, 3. [CrossRef]

39. Desai, L.P.; Chapman, K.E.; Waters, C.M. Mechanical stretch decreases migration of alveolar epithelial cells through mechanisms involving Rac1 and Tiam1. Am. J. Physiol. Lung Cell. Mol. Physiol. 2008, 295, L958-L965. [CrossRef] [PubMed]

40. Vlahakis, N.E.; Hubmayr, R.D. Cellular stress failure in ventilator-injured lungs. Am. J. Respir. Crit. Care Med. 2005, 171, 1328-1342. [CrossRef]

41. Perlman, C.E.; Lederer, D.J.; Bhattacharya, J. Micromechanics of alveolar edema. Am. J. Respir. Cell Mol. Biol. 2010, 44, 34-39. [CrossRef]

42. Mertens, M.; Tabuchi, A.; Meissner, S.; Krueger, A.; Schirrmann, K.; Kertzscher, U.; Pries, A.R.; Slutsky, A.S.; Koch, E.; Kuebler, W.M. Alveolar dynamics in acute lung injury: Heterogeneous distension rather than cyclic opening and collapse. Crit. Care Med. 2009, 37, 2604-2611. [CrossRef]

43. Matthay, M.A.; Zemans, R.L.; Zimmerman, G.A.; Arabi, Y.M.; Beitler, J.R.; Mercat, A.; Herridge, M.; Randolph, A.G.; Calfee, C.S. Acute respiratory distress syndrome. Nat. Rev. Dis. Primers 2018, 307, 2526-2533. [CrossRef]

44. Selman, M.; Pardo, A. Revealing the pathogenic and aging-related mechanisms of the enigmatic idiopathic pulmonary fibrosis: An integral model. Am. J. Respir. Crit. Care Med. 2014, 189, 1161-1172. [CrossRef]

45. Lederer, D.J.; Martinez, F.J. Idiopathic Pulmonary Fibrosis. N. Engl. J. Med. 2018, 378, 1811-1823. [CrossRef]

46. Nonomura, K.; Woo, S.H.; Chang, R.B.; Gillich, A.; Qiu, Z.; Francisco, A.G.; Ranade, S.S.; Liberles, S.D.; Patapoutian, A. Piezo2 senses airway stretch and mediates lung inflation-induced apnoea. Nature 2017, 541, 176-181. [CrossRef]

47. Noble, P.B.; Sharma, A.; McFawn, P.K.; Mitchell, H.W. Elastic properties of the bronchial mucosa: Epithelial unfolding and stretch in response to airway inflation. J. Appl. Physiol. 2005, 99, 2061-2066. [CrossRef]

48. Yu, J. Airway mechanosensors. Respir. Physiol. Neurobiol. 2005, 148, 217-243. [CrossRef] [PubMed]

49. Park, J.A.; Fredberg, J.J.; Drazen, J.M. Putting the squeeze on airway epithelia. Physiology 2015, 30, 293-303. [CrossRef]

50. Li, N.; He, Y.; Yang, G.; Yu, Q.; Li, M. Role of TRPC1 channels in pressure-mediated activation of airway remodeling. Respir. Res. 2019, 20, 91. [CrossRef] [PubMed]

51. Tschumperlin, D.J.; Drazen, J.M. Mechanical stimuli to airway remodeling. Am. J. Respir. Crit. Care Med. 2001, 164, S90-S94. [CrossRef]

52. Copland, I.B.; Kavanagh, B.P.; Engelberts, D.; McKerlie, C.; Belik, J.; Post, M. Early Changes in Lung Gene Expression due to High Tidal Volume. Am. J. Respir. Crit. Care Med. 2003, 168, 1051-1059. [CrossRef]

53. Faisy, C.; Pinto, F.M.; Le Guen, M.; Naline, E.; Delyle, S.G.; Sage, E.; Candenas, M.L.; Devillier, P. Airway response to acute mechanical stress in a human bronchial model of stretch. Crit. Care 2011, 15, R208. [CrossRef] [PubMed]

54. Wells, N.; Roesler, A.M.; Ravix, J.; Teske, J.J.; Pabelick, C.M.; Prakash, Y.S. Mechanical Stretch Contributes to Airway Hyperresponsiveness and Remodeling in Human Fetal Airway Smooth Muscle Cells via the Calcium Sensing Receptor. In A30. Contract and Relax: What's New in Airway Smooth Muscle Mechanisms; American Thoracic Society: New York, NY, USA, 2020.

55. Nucci, G.; Suki, B.; Lutchen, K. Modeling airflow-related shear stress during heterogeneous constriction and mechanical ventilation. J. Appl. Physiol. 2003, 95, 348-356. [CrossRef]

56. Lazarowski, E.R.; Sesma, J.I.; Seminario-Vidal, L.; Kreda, S.M. Chapter 8-Molecular Mechanisms of Purine and Pyrimidine Nucleotide Release. In Advances in Pharmacology: Pharmacology of Purine and Pyrimidine Receptors; Jacobson, K.A., Linden, J., Eds.; Academic Press: Cambridge, MA, USA, 2011; pp. 221-261. ISBN 1054-3589.

57. Tarran, R.; Button, B.; Picher, M.; Paradiso, A.M.; Ribeiro, C.M.; Lazarowski, E.R.; Zhang, L.; Collins, P.L.; Pickles, R.J.; Fredberg, J.J.; et al. Normal and cystic fibrosis airway surface liquid homeostasis: The effects of phasic shear stress and viral infections. J. Biol. Chem. 2005, 280, 35751-35759. [CrossRef]

58. Zhu, Y.; Abdullah, L.H.; Doyle, S.P.; Nguyen, K.; Ribeiro, C.M.P.; Vasquez, P.A.; Forest, M.G.; Lethem, M.I.; Dickey, B.F.; Davis, C.W. Baseline goblet cell mucin secretion in the airways exceeds stimulated secretion over extended time periods, and is sensitive to shear stress and intracellular mucin stores. PLoS ONE 2015, 10, e0127267. [CrossRef] [PubMed]

59. Sidhaye, V.K.; Schweitzer, K.S.; Caterina, M.J.; Shimoda, L.; King, L.S. Shear stress regulates aquaporin-5 and airway epithelial barrier function. Proc. Natl. Acad. Sci. USA 2008. [CrossRef] [PubMed]

60. Bilek, A.M.; Dee, K.C.; Gaver, D.P. Mechanisms of surface-tension-induced epithelial cell damage in a model of pulmonary airway reopening. J. Appl. Physiol. 2003, 94, 770-783. [CrossRef] [PubMed]

61. Ravasio, A.; Hobi, N.; Bertocchi, C.; Jesacher, A.; Dietl, P.; Haller, T. Interfacial sensing by alveolar type II cells: A new concept in lung physiology? Am. J. Physiol. Cell Physiol. 2011, 300, C1456-C1465. [CrossRef]

62. Hobi, N.; Ravasio, A.; Haller, T. Interfacial stress affects rat alveolar type II cell signaling and gene expression. Am. J. Physiol. Lung Cell. Mol. Physiol. 2012, 303, L117-L129. [CrossRef] [PubMed]

63. Mehta, D.; Bhattacharya, J.; Matthay, M.A.; Malik, A.B. Integrated control of lung fluid balance. Am. J. Physiol. Lung Cell. Mol. Physiol. 2004, 287, L1081-L1090. [CrossRef] [PubMed] 
64. Szulcek, R.; Happe, C.M.; Rol, N.; Fontijn, R.D.; Dickhoff, C.; Hartemink, K.J.; Grünberg, K.; Tu, L.; Timens, W.; Nossent, G.D.; et al. Delayed microvascular shear adaptation in pulmonary arterial hypertension: Role of platelet endothelial cell adhesion molecule-1 cleavage. Am. J. Respir. Crit. Care Med. 2016, 193, 1410-1420. [CrossRef]

65. Dickinson, M.G.; Bartelds, B.; Borgdorff, M.A.J.; Berger, R.M.F. The role of disturbed blood flow in the development of pulmonary arterial hypertension: Lessons from preclinical animal models. Am. J. Physiol. Lung Cell. Mol. Physiol. 2013, 305, L1-L14. [CrossRef]

66. Liu, F.; Mih, J.D.; Shea, B.S.; Kho, A.T.; Sharif, A.S.; Tager, A.M.; Tschumperlin, D.J. Feedback amplification of fibrosis through matrix stiffening and COX-2 suppression. J. Cell Biol. 2010, 190, 693-706. [CrossRef] [PubMed]

67. Polio, S.R.; Stasiak, S.E.; Jamieson, R.R.; Balestrini, J.L.; Krishnan, R.; Parameswaran, H. Extracellular matrix stiffness regulates human airway smooth muscle contraction by altering the cell-cell coupling. Sci. Rep. 2019, 9, 9564. [CrossRef] [PubMed]

68. Santos, A.; Lagares, D. Matrix Stiffness: The Conductor of Organ Fibrosis. Curr. Rheumatol. Rep. 2018, 20, 2. [CrossRef] [PubMed]

69. Hinz, B. Tissue stiffness, latent TGF- $\beta 1$ Activation, and mechanical signal transduction: Implications for the pathogenesis and treatment of fibrosis. Curr. Rheumatol. Rep. 2009, 11, 120-126. [CrossRef]

70. Freeberg, M.A.T.; Perelas, A.; Rebman, J.K.; Phipps, R.P.; Thatcher, T.H.; Sime, P.J. Mechanical Feed-Forward Loops Contribute to Idiopathic Pulmonary Fibrosis. Am. J. Pathol. 2021, 191, 18-25. [CrossRef]

71. Chanda, D.; Otoupalova, E.; Smith, S.R.; Volckaert, T.; de Langhe, S.P.; Thannickal, V.J. Developmental pathways in the pathogenesis of lung fibrosis. Mol. Asp. Med. 2019, 65, 56-69. [CrossRef]

72. Marinković, A.; Liu, F.; Tschumperlin, D.J. Matrices of physiologic stiffness potently inactivate idiopathic pulmonary fibrosis fibroblasts. Am. J. Respir. Cell Mol. Biol. 2013, 48, 422-430. [CrossRef]

73. Zhou, Y.; Horowitz, J.C.; Naba, A.; Ambalavanan, N.; Atabai, K.; Balestrini, J.; Bitterman, P.B.; Corley, R.A.; Ding, B.-S.; Engler, A.J.; et al. Extracellular matrix in lung development, homeostasis and disease. Matrix Biol. 2018, 73, 77-104. [CrossRef]

74. Huse, M. Mechanical forces in the immune system. Nat. Rev. Immunol. 2017, 17, 679-690. [CrossRef]

75. Solis, A.G.; Bielecki, P.; Steach, H.R.; Sharma, L.; Harman, C.C.D.; Yun, S.; de Zoete, M.R.; Warnock, J.N.; To, S.D.F.; York, A.G.; et al. Mechanosensation of cyclical force by PIEZO1 is essential for innate immunity. Nature 2019, 573, 69-74. [CrossRef] [PubMed]

76. Button, B.; Boucher, R.C. Role of mechanical stress in regulating airway surface hydration and mucus clearance rates. Respir. Physiol. Neurobiol. 2008, 163, 189-201. [CrossRef] [PubMed]

77. Tschumperlin, D.J.; Drazen, J.M. Chronic effects of mechanical force on airways. Annu. Rev. Physiol. 2006, 68, 563-583. [CrossRef] [PubMed]

78. Veerati, P.C.; Mitchel, J.A.; Reid, A.T.; Knight, D.A.; Bartlett, N.W.; Park, J.-A.; Grainge, C.L. Airway mechanical compression: Its role in asthma pathogenesis and progression. Eur. Respir. Rev. 2020, 29, 190123. [CrossRef]

79. Waters, C.M.; Roan, E.; Navajas, D. Mechanobiology in lung epithelial cells: Measurements, perturbations, and responses. Compr. Physiol. 2012, 2, 1. [CrossRef] [PubMed]

80. Stamenović, D.; Wang, N. Stress transmission within the cell. Compr. Physiol. 2011, 1, 499. [CrossRef]

81. Mathieu, S.; Manneville, J.-B. Intracellular mechanics: Connecting rheology and mechanotransduction. Curr. Opin. Cell Biol. 2019, 56, 34-44. [CrossRef]

82. Hu, X.; Margadant, F.M.; Yao, M.; Sheetz, M.P. Molecular stretching modulates mechanosensing pathways. Protein Sci. 2017, 26, 1337-1351. [CrossRef]

83. Rajan, S.; Schremmer, C.; Weber, J.; Alt, P.; Geiger, F.; Dietrich, A. Ca ${ }^{2+}$ Signaling by TRPV4 Channels in Respiratory Function and Disease. Cells 2021, 10, 822. [CrossRef] [PubMed]

84. Goldenberg, N.M.; Ravindran, K.; Kuebler, W.M. TRPV4: Physiological role and therapeutic potential in respiratory diseases. Naunyn Schmiedebergs Arch. Pharmacol. 2015, 388, 421-436. [CrossRef]

85. Zhong, M.; Komarova, Y.; Rehman, J.; Malik, A.B. Mechanosensing Piezo channels in tissue homeostasis including their role in lungs. Pulm. Circ. 2018, 8, 2045894018767393. [CrossRef] [PubMed]

86. Sun, Z.; Guo, S.S.; Fässler, R. Integrin-mediated mechanotransduction. J. Cell Biol. 2016, 215, 445-456. [CrossRef] [PubMed]

87. Liu, F.; Lagares, D.; Choi, K.M.; Stopfer, L.; Marinković, A.; Vrbanac, V.; Probst, C.K.; Hiemer, S.E.; Sisson, T.H.; Horowitz, J.C.; et al. Mechanosignaling through YAP and TAZ drives fibroblast activation and fibrosis. Am. J. Physiol. Lung Cell. Mol. Physiol. 2015, 308, L344-L357. [CrossRef]

88. Huang, X.; Yang, N.; Fiore, V.F.; Barker, T.H.; Sun, Y.; Morris, S.W.; Ding, Q.; Thannickal, V.J.; Zhou, Y. Matrix stiffness-induced myofibroblast differentiation is mediated by intrinsic mechanotransduction. Am. J. Respir. Cell Mol. Biol. 2012, 47, 340-348. [CrossRef]

89. Zheng, X.R.; Zhang, X. Microsystems for cellular force measurement: A review. J. Micromech. Microeng. 2011, 21, 54003. [CrossRef]

90. Campàs, O. A toolbox to explore the mechanics of living embryonic tissues. Semin. Cell Dev. Biol. 2016, 55, 119-130. [CrossRef] [PubMed]

91. Bonnet, I.; Marcq, P.; Bosveld, F.; Fetler, L.; Bellaïche, Y.; Graner, F. Mechanical state, material properties and continuous description of an epithelial tissue. J. R. Soc. Interface 2012, 9, 2614-2623. [CrossRef]

92. Guirao, B.; Rigaud, S.U.; Bosveld, F.; Bailles, A.; López-Gay, J.; Ishihara, S.; Sugimura, K.; Graner, F.; Bellaïche, Y. Unified quantitative characterization of epithelial tissue development. Elife 2015, 4, e08519. [CrossRef]

93. Evans, E.A.; Kwok, R.; McCown, T. Calibration of beam deflection produced by cellular forces in the $10-9-10-6$ gram range. Cell Biophys. 1980, 2, 99-112. [CrossRef] [PubMed] 
94. Evans, E.; Yeung, A. Apparent viscosity and cortical tension of blood granulocytes determined by micropipet aspiration. Biophys. J. 1989, 56, 151-160. [CrossRef]

95. Hochmuth, R.M. Micropipette aspiration of living cells. J. Biomech. 2000, 33, 15-22. [CrossRef]

96. Guevorkian, K.; Maître, J.L. Micropipette aspiration: A unique tool for exploring cell and tissue mechanics in vivo. Methods Cell Biol. 2017, 139, 187-201. [CrossRef] [PubMed]

97. Maître, J.-L.; Niwayama, R.; Turlier, H.; Nédélec, F.; Hiiragi, T. Pulsatile cell-autonomous contractility drives compaction in the mouse embryo. Nat. Cell Biol. 2015, 17, 849-855. [CrossRef]

98. Cook, T.; Alexander, H.; Cohen, M. Experimental method for determining the 2-dimensional mechanical properties of living human skin. Med. Biol. Eng. Comput. 1977, 15, 381-390. [CrossRef] [PubMed]

99. Aoki, T.; Ohashi, T.; Matsumoto, T.; Sato, M. The pipette aspiration applied to the local stiffness measurement of soft tissues. Ann. Biomed. Eng. 1997, 25, 581-587. [CrossRef]

100. Binnig, G.; Quate, C.F.; Gerber, C. Atomic Force Microscope. Phys. Rev. Lett. 1986, 56, 930. [CrossRef]

101. Franz, C.M.; Puech, P.-H. Atomic Force Microscopy: A Versatile Tool for Studying Cell Morphology, Adhesion and Mechanics. Cell. Mol. Bioeng. 2008, 1, 289-300. [CrossRef]

102. Fotiadis, D.; Scheuring, S.; Müller, S.A.; Engel, A.; Müller, D.J. Imaging and manipulation of biological structures with the AFM. Micron 2002, 33, 385-397. [CrossRef]

103. Dufrêne, Y.F. Atomic force microscopy, a powerful tool in microbiology. J. Bacteriol. 2002, 184, 5205-5213. [CrossRef] [PubMed]

104. Radmacher, M.; Fritz, M.; Hansma, P.K. Imaging soft samples with the atomic force microscope: Gelatin in water and propanol. Biophys. J. 1995, 69, 264-270. [CrossRef]

105. Radmacher, M.; Fritz, M.; Kacher, C.M.; Cleveland, J.P.; Hansma, P.K. Measuring the viscoelastic properties of human platelets with the atomic force microscope. Biophys. J. 1996, 70, 556-567. [CrossRef]

106. Hassan, E.; Heinz, W.F.; Antonik, M.D.; D'Costa, N.P.; Nageswaran, S.; Schoenenberger, C.-A.; Hoh, J.H. Relative Microelastic Mapping of Living Cells by Atomic Force Microscopy. Biophys. J. 1998, 74, 1564-1578. [CrossRef]

107. Benoit, M.; Gaub, H.E. Measuring cell adhesion forces with the atomic force microscope at the molecular level. Cells Tissues Organs 2002, 172, 174-189. [CrossRef] [PubMed]

108. Drake, B.; Prater, C.B.; Weisenhorn, A.L.; Gould, S.A.; Albrecht, T.R.; Quate, C.F.; Cannell, D.S.; Hansma, H.G.; Hansma, P.K. Imaging crystals, polymers, and processes in water with the atomic force microscope. Science 1989, 243, 1586-1589. [CrossRef]

109. Alexander, S.; Hellemans, L.; Marti, O.; Schneir, J.; Elings, V.; Hansma, P.K.; Longmire, M.; Gurley, J. An atomic-resolution atomic-force microscope implemented using an optical lever. J. Appl. Phys. 1989, 65, 164-167. [CrossRef]

110. Meyer, G.; Amer, N.M. Novel optical approach to atomic force microscopy. Appl. Phys. Lett. 1988, 53, 1045-1047. [CrossRef]

111. Moeendarbary, E.; Valon, L.; Fritzsche, M.; Harris, A.R.; Moulding, D.A.; Thrasher, A.J.; Stride, E.; Mahadevan, L.; Charras, G.T. The cytoplasm of living cells behaves as a poroelastic material. Nat. Mater. 2013, 12, 253-261. [CrossRef]

112. Haase, K.; Pelling, A.E. Investigating cell mechanics with atomic force microscopy. J. R. Soc. Interface 2015, 12, 20140970. [CrossRef]

113. Haase, K.; Pelling, A.E. Resiliency of the plasma membrane and actin cortex to large-scale deformation. Cytoskeleton 2013, 70, 494-514. [CrossRef]

114. Kuznetsova, T.G.; Starodubtseva, M.N.; Yegorenkov, N.I.; Chizhik, S.A.; Zhdanov, R.I. Atomic force microscopy probing of cell elasticity. Micron 2007, 38, 824-833. [CrossRef]

115. Darling, E.M.; Topel, M.; Zauscher, S.; Vail, T.P.; Guilak, F. Viscoelastic properties of human mesenchymally-derived stem cells and primary osteoblasts, chondrocytes, and adipocytes. J. Biomech. 2008, 41, 454-464. [CrossRef]

116. Lutz, A.; Jung, D.; Diem, K.; Fauler, M.; Port, F.; Gottschalk, K.; Felder, E. Acute effects of cell stretch on keratin filaments in A549 lung cells. FASEB J. 2020, 34, 11227-11242. [CrossRef]

117. Suresh, S. Biomechanics and biophysics of cancer cells. Acta Biomater. 2007, 3, 413-438. [CrossRef]

118. Li, Q.S.; Lee, G.Y.H.; Ong, C.N.; Lim, C.T. AFM indentation study of breast cancer cells. Biochem. Biophys. Res. Commun. 2008, 374, 609-613. [CrossRef]

119. Petersen, N.O.; McConnaughey, W.B.; Elson, E.L. Dependence of locally measured cellular deformability on position on the cell, temperature, and cytochalasin B. Proc. Natl. Acad. Sci. USA 1982, 79, 5327-5331. [CrossRef]

120. McConnaughey, W.B.; Petersen, N.O. Cell poker: An apparatus for stress-strain measurements on living cells. Rev. Sci. Instrum. 2008, 51, 575. [CrossRef]

121. Duszyk, M.; Schwab, B.; Zahalak, G.I.; Qian, H.; Elson, E.L. Cell poking: Quantitative analysis of indentation of thick viscoelastic layers. Biophys. J. 1989, 55, 683-690. [CrossRef]

122. Daily, B.; Elson, E.L.; Zahalak, G.I. Cell poking. Determination of the elastic area compressibility modulus of the erythrocyte membrane. Biophys. J. 1984, 45, 671-682. [CrossRef]

123. Albrecht-Buehler, G. Role of cortical tension in fibroblast shape and movement. Cell Motil. Cytoskelet. 1987, 7, 54-67. [CrossRef]

124. Kolega, J. Effects of mechanical tension on protrusive activity and microfilament and intermediate filament organization in an epidermal epithelium moving in culture. J. Cell Biol. 1986, 102, 1400-1411. [CrossRef]

125. Dennerll, T.J.; Lamoureux, P.; Buxbaum, R.E.; Heidemann, S.R. The cytomechanics of axonal elongation and retraction. J. Cell Biol. 1989, 109, 3073-3083. [CrossRef] [PubMed]

126. Felder, S.; Elson, E.L. Mechanics of fibroblast locomotion: Quantitative analysis of forces and motions at the leading lamellas of fibroblasts. J. Cell Biol. 1990, 111, 2513-2526. [CrossRef] 
127. Moore, S.W. A fiber optic system for measuring dynamic mechanical properties of embryonic tissues. IEEE Trans. Biomed. Eng. 1994, 41, 45-50. [CrossRef] [PubMed]

128. Zamir, E.A.; Srinivasan, V.; Perucchio, R.; Taber, L.A. Mechanical Asymmetry in the Embryonic Chick Heart during Looping. Ann. Biomed. Eng. 2003, 31, 1327-1336. [CrossRef] [PubMed]

129. Thoumine, O.; Ott, A. Time scale dependent viscoelastic and contractile regimes in fibroblasts probed by microplate manipulation. J. Cell Sci. 1997, 110, 2109-2116. [CrossRef]

130. Thoumine, O.; Ott, A.; Cardoso, O.; Meister, J.-J. Microplates: A new tool for manipulation and mechanical perturbation of individual cells. J. Biochem. Biophys. Methods 1999, 39, 47-62. [CrossRef]

131. Marmottant, P.; Mgharbel, A.; Käfer, J.; Audren, B.; Rieu, J.-P.; Vial, J.-C.; van der Sanden, B.; Marée, A.F.M.; Graner, F.; DelanoëAyari, H. The role of fluctuations and stress on the effective viscosity of cell aggregates. Proc. Natl. Acad. Sci. USA 2009, 106, 17271-17275. [CrossRef]

132. Kalantarian, A.; Ninomiya, H.; Saad, S.M.I.; David, R.; Winklbauer, R.; Neumann, A.W. Axisymmetric drop shape analysis for estimating the surface tension of cell aggregates by centrifugation. Biophys. J. 2009, 96, 1606-1616. [CrossRef]

133. Phillips, H.M.; Steinberg, M.S. Equilibrium Measurements of Embryonic Chick Cell Adhesiveness, I. Shape Equilibrium in Centrifugal Fields. Proc. Natl. Acad. Sci. USA 1969, 64, 121-127. [CrossRef]

134. Ashkin, A. Acceleration and Trapping of Particles by Radiation Pressure. Phys. Rev. Lett. 1970, 24, 156. [CrossRef]

135. Svoboda, K.; Block, S.M. Biological Applications of Optical Forces. Annu. Rev. Biophys. Biomol. Struct. 1994, $23,247-285$. [CrossRef] [PubMed]

136. Kuo, S.C.; Sheetz, M.P. Optical tweezers in cell biology. Trends Cell Biol. 1992, 2, 116-118. [CrossRef]

137. Moffitt, J.R.; Chemla, Y.R.; Smith, S.B.; Bustamante, C. Recent advances in optical tweezers. Annu. Rev. Biochem. 2008, 77, 205-228. [CrossRef] [PubMed]

138. Svoboda, K.; Schmidt, C.F.; Schnapp, B.J.; Block, S.M. Direct observation of kinesin stepping by optical trapping interferometry. Nature 1993, 365, 721-727. [CrossRef] [PubMed]

139. Finer, J.T.; Simmons, R.M.; Spudich, J.A. Single myosin molecule mechanics: Piconewton forces and nanometre steps. Nature 1994, 368, 113-119. [CrossRef] [PubMed]

140. Kucik, D.F.; Kuo, S.C.; Elson, E.L.; Sheetz, M.P. Preferential attachment of membrane glycoproteins to the cytoskeleton at the leading edge of lamella. J. Cell Biol. 1991, 114, 1029-1036. [CrossRef] [PubMed]

141. Dai, J.; Sheetz, M.P. Mechanical properties of neuronal growth cone membranes studied by tether formation with laser optical tweezers. Biophys. J. 1995, 68, 988-996. [CrossRef]

142. Nawaz, S.; Sánchez, P.; Bodensiek, K.; Li, S.; Simons, M.; Schaap, I.A.T. Cell Visco-Elasticity Measured with AFM and Optical Trapping at Sub-Micrometer Deformations. PLoS ONE 2012, 7, e45297. [CrossRef]

143. Guck, J.; Ananthakrishnan, R.; Mahmood, H.; Moon, T.J.; Cunningham, C.C.; Käs, J. The Optical Stretcher: A Novel Laser Tool to Micromanipulate Cells. Biophys. J. 2001, 81, 767-784. [CrossRef]

144. Guck, J.; Ananthakrishnan, R.; Cunningham, C.C.; Käs, J. Stretchingbiological cells with light. J. Phys. Condens. Matter 2002, 14, 4843. [CrossRef]

145. Yang, T.; Bragheri, F.; Minzioni, P. A Comprehensive Review of Optical Stretcher for Cell Mechanical Characterization at Single-Cell Level. Micromachines 2016, 7, 90. [CrossRef]

146. Remmerbach, T.W.; Wottawah, F.; Dietrich, J.; Lincoln, B.; Wittekind, C.; Guck, J. Oral Cancer Diagnosis by Mechanical Phenotyping. Cancer Res. 2009, 69, 1728-1732. [CrossRef]

147. Guck, J.; Schinkinger, S.; Lincoln, B.; Wottawah, F.; Ebert, S.; Romeyke, M.; Lenz, D.; Erickson, H.M.; Ananthakrishnan, R.; Mitchell, D.; et al. Optical Deformability as an Inherent Cell Marker for Testing Malignant Transformation and Metastatic Competence. Biophys. J. 2005, 88, 3689-3698. [CrossRef]

148. Maloney, J.M.; Nikova, D.; Lautenschläger, F.; Clarke, E.; Langer, R.; Guck, J.; van Vliet, K.J. Mesenchymal Stem Cell Mechanics from the Attached to the Suspended State. Biophys. J. 2010, 99, 2479-2487. [CrossRef]

149. Bambardekar, K.; Clément, R.; Blanc, O.; Chardès, C.; Lenne, P.-F. Direct laser manipulation reveals the mechanics of cell contacts in vivo. Proc. Natl. Acad. Sci. USA 2015, 112, 1416-1421. [CrossRef]

150. Fabry, B.; Maksym, G.N.; Butler, J.P.; Glogauer, M.; Navajas, D.; Fredberg, J.J. Scaling the microrheology of living cells. Phys. Rev. Lett. 2001, 87, 148102. [CrossRef]

151. Valberg, P.A.; Feldman, H.A. Magnetic particle motions within living cells. Measurement of cytoplasmic viscosity and motile activity. Biophys. J. 1987, 52, 551-561. [CrossRef]

152. Bausch, A.R.; Möller, W.; Sackmann, E. Measurement of Local Viscoelasticity and Forces in Living Cells by Magnetic Tweezers. Biophys. J. 1999, 76, 573-579. [CrossRef]

153. Wang, N.; Butler, J.P.; Ingber, D.E. Mechanotransduction across the cell surface and through the cytoskeleton. Science 1993, 260, 1124-1127. [CrossRef] [PubMed]

154. Crecea, V.; Ahmad, A.; Boppart, S.A. Magnetomotive optical coherence elastography for microrheology of biological tissues. JBO 2013, 18, 121504. [CrossRef]

155. Liang, X.; Michael, M.; Gomez, G.A. Measurement of Mechanical Tension at Cell-cell Junctions Using Two-photon Laser Ablation. Bio Protoc. 2016, 6, e2068. [CrossRef] 
156. Ma, X.; Lynch, H.E.; Scully, P.C.; Hutson, M.S. Probing embryonic tissue mechanics with laser hole drilling. Phys. Biol. 2009, 6, 36004. [CrossRef]

157. Colombelli, J.; Solon, J. Force communication in multicellular tissues addressed by laser nanosurgery. Cell Tissue Res. 2013, 352, 133-147. [CrossRef]

158. Beloussov, L.V.; Dorfman, J.G.; Cherdantzev, V.G. Mechanical stresses and morphological patterns in amphibian embryos. Development 1975, 34, 559-574. [CrossRef]

159. Nobis, U.; Pries, A.R.; Cokelet, G.R.; Gaehtgens, P. Radial distribution of white cells during blood flow in small tubes. Microvasc. Res. 1985, 29, 295-304. [CrossRef]

160. Dewey, C.F.; Bussolari, S.R.; Gimbrone, M.A.; Davies, P.F. The Dynamic Response of Vascular Endothelial Cells to Fluid Shear Stress. J. Biomech. Eng. 1981, 103, 177-185. [CrossRef]

161. Bacci, C.; Wong, V.; Barahona, V.; Merna, N. Cardiac and lung endothelial cells in response to fluid shear stress on physiological matrix stiffness and composition. Microcirculation 2021, 28, e12659. [CrossRef]

162. Dong, C.; Cao, J.; Struble, E.J.; Lipowsky, H.H. Mechanics of Leukocyte Deformation and Adhesion to Endothelium in Shear Flow. Ann. Biomed. Eng. 1999, 27, 298-312. [CrossRef]

163. Du, V.; Luciani, N.; Richard, S.; Mary, G.; Gay, C.; Mazuel, F.; Reffay, M.; Menasché, P.; Agbulut, O.; Wilhelm, C. A 3D magnetic tissue stretcher for remote mechanical control of embryonic stem cell differentiation. Nat. Commun. 2017, 8, 400. [CrossRef]

164. Gorfien, S.F.; Winston, F.K.; Thibault, L.E.; Macarak, E.J. Effects of biaxial deformation on pulmonary artery endothelial cells. J. Cell. Physiol. 1989, 139, 492-500. [CrossRef]

165. Kulik, T.J.; Alvarado, S.P. Effect of stretch on growth and collagen synthesis in cultured rat and lamb pulmonary arterial smooth muscle cells. J. Cell. Physiol. 1993, 157, 615-624. [CrossRef]

166. Kim, B.-S.; Nikolovski, J.; Bonadio, J.; Mooney, D.J. Cyclic mechanical strain regulates the development of engineered smooth muscle tissue. Nat. Biotechnol. 1999, 17, 979-983. [CrossRef]

167. Harris, A.K.; Wild, P.; Stopak, D. Silicone rubber substrata: A new wrinkle in the study of cell locomotion. Science 1980, 208, 177-179. [CrossRef]

168. Hur, S.S.; Jeong, J.H.; Ban, M.J.; Park, J.H.; Yoon, J.K.; Hwang, Y. Traction Force Microscopy for Understanding Cellular Mechanotransduction. BMB Rep. 2020, 53, 74-81. [CrossRef]

169. Burton, K.; Taylor, D.L. Traction forces of cytokinesis measured with optically modified elastic substrata. Nature 1997, 385, 450-454. [CrossRef]

170. Burton, K.; Park, J.H.; Taylor, D.L. Keratocytes generate traction forces in two phases. Mol. Biol. Cell 1999, 10, 3745-3769. [CrossRef]

171. Lee, J.; Leonard, M.; Oliver, T.; Ishihara, A.; Jacobson, K. Traction forces generated by locomoting keratocytes. J. Cell Biol. 1994, 127, 1957-1964. [CrossRef]

172. Dembo, M.; Wang, Y.-L. Stresses at the Cell-to-Substrate Interface during Locomotion of Fibroblasts. Biophys. J. 1999, 76, $2307-2316$. [CrossRef]

173. Balaban, N.Q.; Schwarz, U.S.; Riveline, D.; Goichberg, P.; Tzur, G.; Sabanay, I.; Mahalu, D.; Safran, S.; Bershadsky, A.; Addadi, L.; et al. Force and focal adhesion assembly: A close relationship studied using elastic micropatterned substrates. Nat. Cell Biol. 2001, 3, 466-472. [CrossRef]

174. Tan, J.L.; Tien, J.; Pirone, D.M.; Gray, D.S.; Bhadriraju, K.; Chen, C.S. Cells lying on a bed of microneedles: An approach to isolate mechanical force. Proc. Natl. Acad. Sci. USA 2003, 100, 1484-1489. [CrossRef] [PubMed]

175. Yang, M.T.; Sniadecki, N.J.; Chen, C.S. Geometric Considerations of Micro- to Nanoscale Elastomeric Post Arrays to Study Cellular Traction Forces. Adv. Mater. 2007, 19, 3119-3123. [CrossRef]

176. Du Roure, O.; Saez, A.; Buguin, A.; Austin, R.H.; Chavrier, P.; Siberzan, P.; Ladoux, B. Force mapping in epithelial cell migration. Proc. Natl. Acad. Sci. USA 2005, 102, 2390-2395. [CrossRef] [PubMed]

177. Xiao, F.; Wen, X.; Tan, X.H.M.; Chiou, P.-Y. Plasmonic micropillars for precision cell force measurement across a large field-of-view. Appl. Phys. Lett. 2018, 112, 33701. [CrossRef]

178. Galbraith, C.G.; Sheetz, M.P. A micromachined device provides a new bend on fibroblast traction forces. Proc. Natl. Acad. Sci. USA 1997, 94, 9114-9118. [CrossRef] [PubMed]

179. German, G.K.; Engl, W.C.; Pashkovski, E.; Banerjee, S.; Xu, Y.; Mertz, A.F.; Hyland, C.; Dufresne, E.R. Heterogeneous Drying Stresses in Stratum Corneum. Biophys. J. 2012, 102, 2424-2432. [CrossRef]

180. Gjorevski, N.; Nelson, C.M. Mapping of Mechanical Strains and Stresses around Quiescent Engineered Three-Dimensional Epithelial Tissues. Biophys. J. 2012, 103, 152-162. [CrossRef]

181. Cho, Y.; Park, E.Y.; Ko, E.; Park, J.-S.; Shin, J.H. Recent advances in biological uses of traction force microscopy. Int. J. Precis. Eng. Manuf. 2016, 17, 1401-1412. [CrossRef]

182. Hur, S.S.; del Álamo, J.C.; Park, J.S.; Li, Y.-S.; Nguyen, H.A.; Teng, D.; Wang, K.-C.; Flores, L.; Alonso-Latorre, B.; Lasheras, J.C.; et al. Roles of cell confluency and fluid shear in 3-dimensional intracellular forces in endothelial cells. Proc. Natl. Acad. Sci. USA 2012, 109, 11110-11115. [CrossRef]

183. Lam, R.H.W.; Sun, Y.; Chen, W.; Fu, J. Elastomeric microposts integrated into microfluidics for flow-mediated endothelial mechanotransduction analysis. Lab Chip 2012, 12, 1865-1873. [CrossRef] 
184. Gavara, N.; Roca-Cusachs, P.; Sunyer, R.; Farré, R.; Navajas, D. Mapping Cell-Matrix Stresses during Stretch Reveals Inelastic Reorganization of the Cytoskeleton. Biophys. J. 2008, 95, 464-471. [CrossRef]

185. Zhou, J.; Pal, S.; Maiti, S.; Davidson, L.A. Force production and mechanical accommodation during convergent extension. Development 2015, 142, 692-701. [CrossRef]

186. Campàs, O.; Mammoto, T.; Hasso, S.; Sperling, R.A.; O'Connell, D.; Bischof, A.G.; Maas, R.; Weitz, D.A.; Mahadevan, L.; Ingber, D.E. Quantifying cell-generated mechanical forces within living embryonic tissues. Nat. Methods 2014, 11, 183-189. [CrossRef]

187. Miyawaki, A. Development of probes for cellular functions using fluorescent proteins and fluorescence resonance energy transfer. Annu. Rev. Biochem. 2011, 80, 357-373. [CrossRef] [PubMed]

188. Meng, F.; Suchyna, T.M.; Sachs, F. A fluorescence energy transfer-based mechanical stress sensor for specific proteins in situ. FEBS J. 2008, 275, 3072-3087. [CrossRef]

189. Grashoff, C.; Hoffman, B.D.; Brenner, M.D.; Zhou, R.; Parsons, M.; Yang, M.T.; McLean, M.A.; Sligar, S.G.; Chen, C.S.; Ha, T.; et al. Measuring mechanical tension across vinculin reveals regulation of focal adhesion dynamics. Nature 2010, 466, 263-266. [CrossRef] [PubMed]

190. Kong, H.J.; Polte, T.R.; Alsberg, E.; Mooney, D.J. FRET measurements of cell-traction forces and nano-scale clustering of adhesion ligands varied by substrate stiffness. Proc. Natl. Acad. Sci. USA 2005, 102, 4300-4305. [CrossRef] [PubMed]

191. Borghi, N.; Sorokina, M.; Shcherbakova, O.G.; Weis, W.I.; Pruitt, B.L.; Nelson, W.J.; Dunn, A.R. E-cadherin is under constitutive actomyosin-generated tension that is increased at cell-cell contacts upon externally applied stretch. Proc. Natl. Acad. Sci. USA 2012, 109, 12568-12573. [CrossRef]

192. Freikamp, A.; Cost, A.-L.; Grashoff, C. The Piconewton Force Awakens: Quantifying Mechanics in Cells. Trends Cell Biol. 2016, 26, 838-847. [CrossRef]

193. Poh, Y.-C.; Shevtsov, S.P.; Chowdhury, F.; Wu, D.C.; Na, S.; Dundr, M.; Wang, N. Dynamic force-induced direct dissociation of protein complexes in a nuclear body in living cells. Nat. Commun. 2012, 3, 866. [CrossRef]

194. Göhring, J.; Kellner, F.; Schrang, L.; Platzer, R.; Klotzsch, E.; Stockinger, H.; Huppa, J.B.; Schütz, G.J. Temporal analysis of T-cell receptor-imposed forces via quantitative single molecule FRET measurements. Nat. Commun. 2021, 12, 2502. [CrossRef] [PubMed]

195. Guo, M.; Ehrlicher, A.J.; Jensen, M.H.; Renz, M.; Moore, J.R.; Goldman, R.D.; Lippincott-Schwartz, J.; Mackintosh, F.C.; Weitz, D.A Probing the Stochastic, Motor-Driven Properties of the Cytoplasm Using Force Spectrum Microscopy. Cell 2014, 158, 822-832. [CrossRef] [PubMed]

196. Caspi, A.; Granek, R.; Elbaum, M. Enhanced Diffusion in Active Intracellular Transport. Phys. Rev. Lett. 2000, 85, 5655-5658. [CrossRef] [PubMed]

197. Lau, A.W.C.; Hoffman, B.D.; Davies, A.; Crocker, J.C.; Lubensky, T.C. Microrheology, stress fluctuations, and active behavior of living cells. Phys. Rev. Lett. 2003, 91, 198101. [CrossRef] [PubMed]

198. Yamada, S.; Wirtz, D.; Kuo, S.C. Mechanics of Living Cells Measured by Laser Tracking Microrheology. Biophys. J. 2000, 78, 1736-1747. [CrossRef]

199. Weihs, D.; Mason, T.G.; Teitell, M.A. Bio-microrheology: A frontier in microrheology. Biophys. J. 2006, 91, 4296-4305. [CrossRef]

200. Mandal, K.; Asnacios, A.; Goud, B.; Manneville, J.-B. Mapping intracellular mechanics on micropatterned substrates. Proc. Natl. Acad. Sci. USA 2016, 113, E7159-E7168. [CrossRef]

201. Curtis, A.; Sokolikova-Csaderova, L.; Aitchison, G. Measuring Cell Forces by a Photoelastic Method. Biophys. J. 2007, 92, 2255-2261. [CrossRef]

202. Sugimura, K.; Lenne, P.-F.; Graner, F. Measuring forces and stresses in situ in living tissues. Development 2016, 143, 186-196. [CrossRef]

203. Prevedel, R.; Diz-Muñoz, A.; Ruocco, G.; Antonacci, G. Brillouin microscopy: An emerging tool for mechanobiology. Nat. Methods 2019, 16, 969-977. [CrossRef]

204. Scarcelli, G.; Yun, S.H. Confocal Brillouin microscopy for three-dimensional mechanical imaging. Nat. Photon 2008, 2, 39-43. [CrossRef] [PubMed]

205. Stein, M.B.; Gordon, R. Epithelia as bubble rafts: A new method for analysis of cell shape and intercellular adhesion in embryonic and other epithelia. J. Theor. Biol. 1982, 97, 625-639. [CrossRef]

206. Brodland, G.W.; Veldhuis, J.H.; Kim, S.; Perrone, M.; Mashburn, D.; Hutson, M.S. CellFIT: A cellular force-inference toolkit using curvilinear cell boundaries. PLoS ONE 2014, 9, e99116. [CrossRef]

207. Chiou, K.K.; Hufnagel, L.; Shraiman, B.I. Mechanical Stress Inference for Two Dimensional Cell Arrays. PLOS Comput. Biol. 2012, 8, e1002512. [CrossRef] [PubMed]

208. Sugimura, K.; Ishihara, S. The mechanical anisotropy in a tissue promotes ordering in hexagonal cell packing. Development 2013, 140, 4091-4101. [CrossRef] [PubMed]

209. Ishihara, S.; Sugimura, K. Bayesian inference of force dynamics during morphogenesis. J. Theor. Biol. 2012, 313, $201-211$. [CrossRef]

210. Bachofen, H.; Schürch, S. Alveolar surface forces and lung architecture. Comp. Biochem. Physiol. Part A 2001, 129, 183-193. [CrossRef]

211. Vogel, V. Unraveling the Mechanobiology of Extracellular Matrix. Annu. Rev. Physiol. 2018, 80, 353-387. [CrossRef] [PubMed]

212. Uto, K.; Tsui, J.H.; DeForest, C.A.; Kim, D.-H. Dynamically tunable cell culture platforms for tissue engineering and mechanobiology. Prog. Polym. Sci. 2017, 65, 53-82. [CrossRef] [PubMed] 
213. Mammoto, T.; Mammoto, A.; Ingber, D.E. Mechanobiology and Developmental Control. Annu. Rev. Cell Dev. Biol. 2013, 29 , 27-61. [CrossRef] [PubMed]

214. Smith, L.R.; Cho, S.; Discher, D.E. Stem Cell Differentiation is Regulated by Extracellular Matrix Mechanics. Physiology 2018, 33, 16-25. [CrossRef] [PubMed]

215. Kim, S.; Uroz, M.; Bays, J.L.; Chen, C.S. Harnessing Mechanobiology for Tissue Engineering. Dev. Cell 2021, 56, $180-191$. [CrossRef] [PubMed] 